\title{
Evaluation of Six Breeding Lines of Milk Goats
}

\author{
John Hayward Sanfiorenzo ${ }^{1}$
}

\section{INTRODUCTION}

Goats are a potential asset to the economy of Puerto Rico. They are a good source of milk and meat and can use efficiently thousands of acres of land in the Island that are at present unproductive.

The population of goats is small in most parts of the Island. This seems to be due to a lack of sources of breeding stock which are necessary for establishing new herds.

Some Federal agencies, private institutions, and a few progressive farmers, have tried to overcome this drawback by importing representatives of several breeds from the United States. The number of imported goats rapidly diminished because of lack of adaptability to both the natural and man-made environment.

The Agricultural Experiment Station has been working on a crossbreeding program with the purpose of developing a strain or breed of goats that will be adapted to Puerto Rican conditions. At the same time the Station has been helping the goat-raisers by supplying them bucks of good breeding. Up to the present it has been impossible to supply the larger number of females that have been requested.

This study is mainly concerned with the selection of the most promising lines of breeding in the Station project.

\section{REVIEW OF LITERATURE}

The effect of top-crossing with purebred bucks on the milk yield of does has been studied by several research workers. Simmons and Lambert (4) ${ }^{2}$ studied the effect of grading-up does of common breeding with purebred bucks of the Saanen and Toggenburg breeds. The improvement in milk production was similar for top-cross does of both breeds and marked increases in milk production were obtained, some of them almost equaling the production of the purebred females. The New Mexico Agricultural Experiment Station (4) obtained similar results from top-crossed Toggenburg-Native does. Sanfiorenzo (3) obtained similar results and concluded that the most suitable cross for developing a useful strain for the conditions of Puerto Rico, was the Saanen-Native cross.

Several workers have studied the effect of the age of doe on milk produc-

1 Assistant Animal Husbandman, Agricultural Experiment Station, University of Puerto Rico, Río Piedras, P.R.

2 Italic numbers in parentheses refer to Literature Cited p. 212. 
tion. Bonnekamp (1), studying the course of lactation and the relation between consecutive lactations of goats in Germany, found that the milk yield rose with advancing age until the fifth lactation, stayed nearly unchanged during the sixth and seventh lactations, and then declined. Simmons and Lambert (4) found that the period of maximum milk production for does was between 4 and 6 years of age. Watkin (5) studying 600 officially recorded lactations of six herds in England and Wales, found that it was difficult to evaluate the effect of age on total yield. First, it was difficult to obtain a sufficient number of lactations on comparable goats. Second, the average figures obtained were rather misleading, since some goats showed increases in yields even in their sixth and seventh lactations. However, Watkin found that about 20 percent of the goats reached their maximum yields in the second or third lactation, and then decreased to the seventh at the rate of 10 percent per lactation. Sanfiorenzo ( $(S)$ found that there was a general upward trend in milk production with succeeding years or lactations. However, the increases were small and rather misleading since some groups showed consecutive increases in the three age periods, while other groups showed increases in the second period and decreases in the third. Still other groups showed decreases in the second period and increases in the third.

\section{MATERIALS AND METHODS}

The data used in this study were taken from the records of does and kids of a project for the improvement of the native milk goat of Puerto Rico. These data include 155 records of 73 goats and 375 records from kids covering the period from 1955 to 1959 , inclusive. Goats were milked to a 270-day lactation period and all records were adjusted to lifetime averages by the Lush (2) method of averages. Kids that were sold between the age groups were not included in the study.

All goats were under the same management procedure except for some purebred Saanen does that on some occasions were confined to small pens and kept under special care in order to improve their physical condition. Goats were milked twice daily by hand until June 1958 when mechanical milkers were installed.

Kids were with their dams for 4 days. Afterwards milk was fed to them by means of artificial gang-feeders. Hay of Pangola or Bermuda grasses was available to them until 1 year of age. The milk ration was replaced gradually by concentrate to a maximum of $1 \frac{1}{2}$ pounds of concentrate per kid.

Does were wormed monthly with phenotiazine and lead arsenate taboles. Kids received a low level phenotiazine treatment in addition to monthly treatment with cupper sulfate and lead arsenate tablets. 
A multiple correlation analysis was conducted on both milk production and mortality data.

The sources of variation in the milk-production analysis were as follows:

1. Breeding Lines: $1 / 2$ Saanen $\times 1 / 4$ Barbado $\times 1 / 4$ Native; Saanen; $3 / 4$ Saanen $\times 1 / 4$ Native; $7 / 8$ Saanen $\times 1 / 8$ Native; 1/2 Saanen $\times 1 / 2 \mathrm{Na}$ tive; Native.

2. Years: $1955,1956,1957,1958,1959$.

3. Age of does: 2 years, 3 years, 4 years, 5 years, 6 years.

In the mortality analysis, breeding lines and years were as above while the age groups were as follows: Birth to 1 month of age, 2 to 6 months of age, and 7 to 12 months of age.

TABLE 1.-Effect of breeding lines on milk production of does adjusted for year and age of does

\begin{tabular}{|c|c|c|c|}
\hline \multirow{2}{*}{ Breeding lines } & \multirow{2}{*}{ Records } & \multicolumn{2}{|c|}{ Milk production } \\
\hline & & Adjusted means & $\begin{array}{l}\text { Deviation from } \\
\text { adjusted mean }\end{array}$ \\
\hline & Ntmber & Pounds & Pounds \\
\hline $1 / 2$ Saanen $\times 1 / 4$ Barbado $\times 1 / 4$ Native & 5 & 655.5 & +7.6 \\
\hline Saanen & 23 & 642.0 & +6.2 \\
\hline $3 / 4$ Saanen $\times 1 / 4$ Native & 29 & 626.8 & +4.7 \\
\hline $7 / 8$ Saanen $\times$ I/s Native & 19 & 600.1 & +2.1 \\
\hline $1 / 2$ Saanen $\times 1 / 2$ Native & 17 & 539.0 & -4.1 \\
\hline Native & 62 & 414.6 & -16.5 \\
\hline
\end{tabular}

The studentized range ( $Q$ test) was used to determine degree of significance of the differences between mean responses.

\section{EXPERIMENTAL RESULTS}

\section{ANALYSIS OF MILK PRODUCTION OF DOFS}

\section{Breeding Lines}

No significant differences were observed between the following breeding lines: $1,1 / 2$ Saanen $\times 1 / 4$ Barbado $\times 1 / 4$ Native; 2 , Saanen; 3, 3/4 Saanen $\times$ $1 / 4$ Native; $4,7 / 8$ Saanen $\times 1 / 8$ Native. The Saanen breed and all crossbreds outyielded the Native Breed at the 1-percent level. The 7/8 Saanen $\times 1 / 8$ Native and the $3 / 4$ Saanen $\times 1 / 4$ Native outyielded at the 5-percent level the $1 / 2$ Saanen $\times 1 / 2$ Native cross, while the Saanen and the 1/2 Saanen $\times$ $1 / 4$ Barbado $\times 1 / 4$ Native outyielded this same crossbred at the 1-percent level. The adjusted means of milk production for lines are shown in table 1. 


\section{Years}

Differences between years 1957 to 1959 were not significant. Highly significant differences were observed between years 1957-58 and years 1955-56. Significant differences were observed between year 1959 and years 1955-56. The adjusted means of milk production for years are shown in table 2.

TABI.E 2.-Effect of years on milk production of does adjusled for breeding lines and for age of does, 1955-59

\begin{tabular}{c|c|c|c}
\hline \multirow{2}{*}{ Years } & \multirow{2}{*}{ Records } & \multicolumn{2}{|c}{ Milk production } \\
\cline { 2 - 3 } & & Adjusted means & $\begin{array}{c}\text { Deviation from adjusted } \\
\text { mean }\end{array}$ \\
\hline & Number & Pounds & Pounds \\
1955 & 10 & 530.8 & -4.9 \\
1956 & 28 & 541.1 & -3.9 \\
1957 & 35 & 607.6 & +2.7 \\
1958 & 40 & 628.3 & +4.9 \\
1959 & 42 & 590.9 & +1.2 \\
\hline
\end{tabular}

TABLE 3.-Effect of age on milk production of does adjusted for breeding lines and for year

\begin{tabular}{c|c|c|c}
\hline \multirow{2}{*}{ Age of does (years) } & \multirow{2}{*}{ Records } & \multicolumn{2}{|c}{ Milk production } \\
\cline { 2 - 3 } & & Adjusted means & $\begin{array}{c}\text { Devintion from adjusted } \\
\text { mean }\end{array}$ \\
\cline { 2 - 4 } & Number & Pounds & Pounds \\
2 & 52 & 486.7 & -9.3 \\
3 & 38 & 541.4 & -3.8 \\
4 & 35 & 590.4 & +1.1 \\
5 & 19 & 634.2 & +5.4 \\
6 & 11 & 645.9 & +6.6 \\
\hline
\end{tabular}

Age of Does

Differences in milk production between does 4 to 6 years old were not significant. Does 4 to 6 years old outyielded does 2 to 3 years old and does 3 years old outyielded does 2 years old at the 1-percent level. Adjusted means of milk production for age groups are shown in table 3.

\section{ANALYSIS OF MORTALITY IN KIDS}

\section{Breeding Lines}

No significant differences in mortality were observed between lines. Adjusted means of percentages of mortality for lines are shown in table 4 . 


\section{Years}

Significant differences were observed between years 1958 and 1959 and year 1955. No significant differences were observed between the other years. Adjusted means of mortality for years are shown in table 5 .

\section{Age of Kids}

Mortality from 2 to 6 months of age was significant at the 5-percent level over mortality from birth to 1 month of age and from 7 to 12 months age.

TABLE 4.-Effect of breeding lines on morlalily of kids adjusied for year and for age of kids

\begin{tabular}{|c|c|c|c|}
\hline \multirow{2}{*}{ Breeding lines } & \multirow{2}{*}{ Records } & \multicolumn{2}{|c|}{ Mortality } \\
\hline & & Adjusted means & $\begin{array}{l}\text { Deviation from } \\
\text { adjusted mean }\end{array}$ \\
\hline $\begin{array}{l}1 / 2 \text { Saanen } \times 1 / 4 \text { Barbudo } \times 1 / 4 \text { Native } \\
\text { Saanen } \\
3 / 4 \text { Saanen } \times 1 / 4 \text { Native } \\
7 / 8 \text { Saanen } \times 1 / 8 \text { Native } \\
1 / 2 \text { Saanen } \times 1 / 2 \text { Native } \\
\text { Native }\end{array}$ & $\begin{array}{c}\text { Number } \\
110 \\
38 \\
50 \\
19 \\
92 \\
66\end{array}$ & $\begin{array}{c}\text { Percent } \\
7.7 \\
13.9 \\
11.2 \\
13.2 \\
16.6 \\
15.8\end{array}$ & $\begin{array}{c}\text { Percent } \\
-5.4 \\
+\quad .9 \\
-1.9 \\
+.1 \\
+3.5 \\
+2.8\end{array}$ \\
\hline
\end{tabular}

TABLE 5.-Effect of years on mortalily of kids adjusted for breeding lines and for age of kids

\begin{tabular}{c|c|c|c}
\hline \multirow{2}{*}{ Years } & \multirow{2}{*}{ Records } & \multicolumn{2}{|c}{ Mortality of kids } \\
\cline { 2 - 3 } & & Adjusted means & $\begin{array}{c}\text { Deviation from } \\
\text { adjusted mean }\end{array}$ \\
\hline & Number & Percent & Percent \\
1955 & 39 & 0.4 & -12.6 \\
1956 & 46 & 16.2 & +3.2 \\
1957 & 80 & 9.8 & -3.3 \\
1958 & 102 & 18.5 & +5.4 \\
1959 & 108 & 20.3 & +7.3 \\
\hline
\end{tabular}

Differences in mortality from birth to 1 month of age and from 7 to 12 months of age were not significant. Adjusted means of mortality percentages of the different age groups are shown in table 6.

\section{DISCUSSION}

\section{ANALYSIS OF MILK PRODUCTION OF DOES}

Examination of table 1 shows that substantial increases in milk production were obtained from top-crosses. These results are similar to those ob- 
tained by the New Mexico Agricultural Experiment Station and by Simmons and Lambert (9). The $1 / 2$ Saanen $\times 1 / 4$ Barbados $\times 1 / 4$ Native crossbreds were the heaviest milk producers, followed closely by the Saanen purebreds, the $3 / 4$ Saanen $\times 1 / 4$ Native, and the $7 / 8$ Saanen $\times 1 / 8$ Native. Since the Native breed was inferior at a highly significant level to all crossbreds, the worth of grading-up the Native stock is evident.

The means in table 3 indicate that the trend in milk production of does is to increase with age up to 6 years of age. Further studies should be conducted to determine the trend after 6 years of age. Maximum milk production was obtained from does 4 to 6 years old. These results are similar to those of Bonnekamp (1) and of Simmons and Lambert (4).

The effect of years on milk production followed a similar trend to the effect of age. Variations among years found in this study are attributed in

TABLE 6.-Effect of age on mortality of kids adjusted for breeding lines and for year

\begin{tabular}{c|c|c|c}
\hline \multirow{2}{*}{ Age (months) } & Records & \multicolumn{2}{|c}{ Mortality of kids } \\
\cline { 2 - 3 } & & Adjusted means & $\begin{array}{c}\text { Deviation from } \\
\text { adjusted mean }\end{array}$ \\
\hline & Number & Percent & Percent \\
Birth to 1 & 375 & 8.9 & -4.1 \\
2 to 6 & 310 & 20.5 & +7.5 \\
7 to 12 & 196 & 9.7 & -3.4 \\
\hline
\end{tabular}

part to variations among the different age groups, and in part, to variations in environmental conditions beyond the control of the breeder.

\section{ANALYSIS OF MOIRTALITY IN KIDS}

Differences in mortality percentages between lines are not of importance. The 3-way cross, 1/2 Saanen $\times 1 / 4$ Barbados, $\times 1 / 4$ Native, had the lowest mortality percentage while the highest mortality occurred in the 1/2 Saanen $\times 1 / 2$ Native cross.

Differences in mortality between years are considered of little importance also. Increased competition and crowding of kids in the pens have contributed to the higher mortality percentages during years 1958 and 1959 . Under crowded conditions parasite infestations are favored, resulting in severe losses from this cause.

Examination of table 6 shows that more kids died at from 2 to 6 months of age than from birth to 1 month of age or from 7 to 12 months of age. These differences were significant at the 5-percent level. 


\section{SUMMARY}

A multiple correlation analysis was conducted on milk production and on mortality data to evaluate the following six breeding lines of milk goats: Saanen, Native, $1 / 2$ Saanen $\times 1 / 2$ Native, 3/4 Saanen $\times 1 / 4$ Native, $7 / 8$ Saanen $\times 1 / 8$ Native, and $1 / 2$ Saanen $\times 1 / 4$ Barbados $\times 1 / 4$ Native. The sources of variation were: Breeding lines; year; age of does; and age of kids. These data included 155 records of 73 does and 375 records of kids, and covered the period from 1955 to 1959 , inclusive.

All lines outyielded at a highly significant level the milk production of the Native breed. The heaviest milk producer was the 3 -way cross; $1 / 2$ Saanen $\times 1 / 4$ Barbados $\times 1 / 4$ Native, followed closely by the Saanen breed, the $3 / 4$ Saanen $\times 1 / 4$ Native, and the $7 / 8$ Saanen $\times 1 / 8$ Native. Differences between lines mentioned were not significant.

Highly significant differences in milk production were observed between ages of does. Milk production increased with age until 6 years of age. There were no data available after 6 years of age. Maximum milk production was obtained from does 4 to 6 years old.

Variations in milk production among years were attributed, in part, to variations among the different age groups, and in part, to variations in environmental conditions beyond the control of the breeder.

Differences in mortality percentages between lines were not significant. The 3-way cross, 1/2 Saanen $\times 1 / 4$ Barbados $\times 1 / 4$ Native, had the lowest mortality percentage, while the highest occurred in the 1/2 Saanen $\times$ 1/2 Native cross.

Differences in mortality among years were not considered of importance. It was concluded that crowding and increased competition contributed to the variations observed.

More kids died from 2 to 6 months of age than from birth to 1 month of age, and than from 7 to 12 months of age. These differences were significant at the is-percent level.

\section{RESUMEN}

Este estudio comprende un análisis de los récords de producción de leche y de mortandad en cabritos con el propósito de evaluar las siguientes seis líneas de cabras: Saanen, Nativa, 1/2 Saanen $\times 1 / 2$ Nativa, 3/4 Saanen $\times 1 / 4$ Nativa, $7 / 8$ Saanen $\times 1 / 8$ Nativa y $1 / 2$ Saanen $\times 1 / 4$ Barbada $\times 1 / 4$ Nativa. Las fuentes de variación estudiadas fueron como sigue: Líneas de cruzamiento; año, edad de las cabras, y edad de los cabritos. La información incluyó 155 récords de 73 cabras lecheras y 375 récords de cabritos. El estudio cubre el período de 1955 al 1959, ambos años inclusive.

Todas las líneas superaron significativamente la producción de leche de 
las cabras nativas. El promedio de produsción de leche más alto lo tuvo el cruce triple: $1 / 2$ Saanen $\times 1 / 4$ Barbada $\times 1 / 4$ Nativa. Le siguieron en orden descendente la raza Saanen, y los cruces $3 / 4$ Samen $\times 1 / 4$ Nativa y $7 / 8$ Saanen $\times 1 / 8$ Nativa.

Las diferencias en producción de leche entre las diferentes edades fueron altamente significativas. La producción de leche aumentó con la edad hasta los 6 años. No hubo información en cuanto a edades mayores de 6 años. La producción máxima se obtuvo de cabras de los 4 a los 6 años de edad.

Se observaron variaciones entre la producción de leche de algunos años. Estas variaciones se atribuyen, en parte, a la tendencia de las cabras a aumentar su producción de leche según van teniendo más edad, y en parte, a las variaciones ambientales que son incontrolables.

Las diferencias en el porcentaje de mortandad entre las líneas no fueron significativas. El porcentaje de mortandad más bajo ocurrió en el cruce triple: $1 / 2$ Saanen $\times 1 / 4$ Barbada $\times 1 / 4$ Nativa, mientras que el más alto ocurrió en el cruce $1 / 2$ Saanen $\times 1 / 2$ Nativa.

Las diferencias en mortandad entre años se consideraron de menor importancia. El aumento en competencia, al agrupar un número alto de cabritos en corrales pequeños, contribuyó a las variaciones observadas.

El porcentaje mortandad fué mayor en cabritos de 2 a 6 meses de edad, que en los de hasta 1 mes; y que en los de 7 a 12 meses. Estas diferencias fueron significativas al nivel del 5 por ciento.

\section{LITERATURE CITED}

1. Bonnekamp, H., Course of lactation in goats, reliability of various methods of milk control, Z. Tierz. Zücht. Biol. 42 429-62, 1939.

2. Lush, Jay L., Animal Breeding Plans, 3d ed., Iowa State College Press, Ames, Iowa, 1945.

3. Sanfiorenzo, John H., A study of milk production by Native, Barbados and Crossbred goats in Puerto Rico, Agr. Exp. Sta. Univ. P.R., Bul. 139, 1957.

4. Simmons, V. L., and Lambert, W. V., Improvement of milk goats, USDA Yearbook 1937, pp. 1294-312, 1937.

5. Watkin, J. E., and Knowles, E., The Influence of Age and of Factors Causing Variation during Lactation on Milk Yield of the Goat, British Goat Society Yearbook, Diss, England 1946., pp. 4-12, 1946. 